\title{
弆司 兵
}

\section{西}

\section{理工学分野における ジェンダーバランスの現状と課題}

\section{1 現状及び問題点}

令和元年版の男女共同参画白書によれば、我が国における研究者に占める女性の割合は、緩やかな上 昇傾向にあるものの、平成 30 年 3 月 31 日現在で $16.2 \%$ にどまっている。この数字は諸外国と比べて低 く、男女共同参画の実現には遠い現状を示している。理学・工学分野では、数值はさらに梁刻なものに なる。大学研究等の研究本務者の男女別割合（平成 29 年）は、理学 (14.2\%)、工学 (10.6\%) であり、 専門分野別にみれば理学・工学各分野の女性研究者割合の低さは明白である。理工学分野における女性 研究者・技術者の割合を増大させ、男女共同参画社会を実現させるためにも、若い世代が自由な進路選 択をすることができるような環境づくりと有効な支援体制の確立が重要であろう。

近年では、公的機関、民間企業、大学、学協会等においても、理工系への女子生徒の進路選択支援の ための活動が行われている。これらは一定の効果を挙げているが、理工学における男女共同参画を加速 するには、これまでの取り組み以上の働きかけが必要である。理工学分野への選択に最も大きく影響し ているのは初等中等教育環境であろう。小学校では算数、理科が好きな子どもが男女問わず 6 割以上い るが、中学生になると数学・理科が好きな生徒は、男子は 6 割を上回るものの、女子では 4 から 5 割に下 がってしまう。これは単なる適性の問題ではなく、周辺環境が影響していると考えられる。

現在日本は高齢化が進み、労働人口の減少や経済の停滞が懸念される状況にある。その中で、高度な 教育を受けた女性が活躍しやすくすることは、理にかなっていると考えられる。女性が活躍できる環境 づくりは、子ども、高齢者、妊婦、育児中の人、病弱の人、要介護者、障害者、外国人など様々な人々 の視点に立つことに通じる。ジェンダー・ダイバーシティの問題は、自分が弱い立場におかれていない 人には見えないと言われている。伝統的家族観が根強い日本の政治経済の指導層や社会の管理的な立場 にある人々こそ、無意識の偏見（アンコンシャスバイアス）について、今一度考える機会を持つ必要が ある。

\section{2 報告の内容}

（1）理工学各分野における男女共同参画に関する取組みの分析

本報告では、環境学、数理科学、物理学、地球惑星科学、情報学、化学、総合工学、機械工学、電気 電子工学、土木工学・建築学、材料工学のそれぞれの分野、大学等での現状と取組みを分析した。分野 により 5 〜 20\%とその割合も異なるが、共通して言えることは、様々な取り組みがなされているにも関 
わらず、理工学分野における女性研究者の割合は、海外に比べて改善のスピードが緩慢で、依然として 極めて低い状況にあるということである。大学、大学院、企業やアカデミアの研究者と進んでいく中で 女性割合が減少していくという事実が厳然とあり、これは、環境に依存したものと言わざるを得ない。 リーキーパイプラインと呼ばれるこのような現状の課題を克服するためには、各段階で継続のための支 援をより手厚くする方策をとっていく必要がある。

（2）課題解決に向けた高等教育機関へのアプローチ

大学、公的研究機関等においても概ね「男女共同参画支援室」が設置され、様々な支援を行っている。 改革途上で不十分な点は否定しないが、女性が勉学や仕事を継続して行える環境は確実に改善されてき ている。また、積極的に女性研究者を登用する方針により増加の効果は現れている。ここでより注目し たいのは、理工学分野の女性研究者割合の増加をいかにして加速するかという点にある。まずは、学部 学生、大学院修士課程、博士課程に従って女性の割合が減少する事実を解消する必要がある。経済支援 も拡充すべきであるが、それとともに、勉学・研究を継続できる環境をより積極的に整える必要がある。 大学・研究室での指導者、共同研究者、同僚、家族、当人自身が男女の性差に対して無意識に持つ考え を改めて見直し、意識改革を意識して行わなくては変わらない。

（3）課題解決に向けた初等中等教育機関へのアプローチ

日本の教育制度では、大学への進学にあたって、生徒は理系か文系かの進路選択を迫られる。高等専 門学校への進学においては、中学生の時点での文理選択になる。進路選択において、家族や親戚、ある いは、教師の影響は大きく、身の回りにロールモデルが少ないことなどから女性が理系に進むことに反 対するような場合も多いと考えられる。周りの大人たちの無意識のバイアスを払拭していくことが何よ りも重要であり、理工系進路選択への理解を進めるための情報提供が重要であろう。

（4）課題解決に向けた家庭・社会などへのアプローチ

理工学への関心を高めるために行われる大学や学協会の様々なイベントも、いわゆる “意識の高い” 層に限られていれば格段の効果は望めない。関心のない層への切込みが必要である。そのためには、男 女の役割として根付いた伝統や旧来の社会的風潮に目を向ける必要がある。特に地方では、昔ながらの 伝統や風習が時として女子生徒の自由な選択の妨げになる。伝統も時代に合わせて変わりうるものであ り、新しい社会的風潮や流れを積極的に作り出していく必要がある。ここでマスメデイアの果たすべき 役割は大きい。また、公共広告などの手段を用いて関連施策の一層の推進を図るべきである。 